\title{
Obstructive sleep apnea affects the clinical outcomes of patients undergoing percutaneous coronary intervention [Corrigendum]
}

\author{
Zhang JJ, Gao XF, Ge Z, et al. Patient Prefer Adherence.
} 2016;10:871-878.

The authors belatedly note an error in their methodology, and advise that the data for the obstructive sleep apnea (OSA) group is therefore flawed.

The authors also note that Chi-Hang Lee should not have been included in the author list, therefore the author and affiliation list should have been:

Jun-jie Zhang ${ }^{1,2, *}$

Xiao-fei Gao ${ }^{1, *}$

Zhen $\mathrm{Ge}^{1,2}$

Xiao-Min Jiang ${ }^{1}$

Ping-xi Xiao ${ }^{1,2}$

Nai-liang Tian ${ }^{1,2}$

Jing Kan ${ }^{2}$

Shao-Liang Chen ${ }^{1,2}$

${ }^{1}$ Department of Cardiology, Nanjing First Hospital, Nanjing Medical University, ${ }^{2}$ Department of Cardiology, Nanjing Heart Center, Nanjing, People's Republic of China

*These authors contributed equally to this work open access journal that focuses on the growing importance of patient preference and adherence throughout the therapeutic continuum. Patient satisfaction, acceptability, quality of life, compliance, persistence and their role in developing new therapeutic modalities and compounds to optimize

clinical outcomes for existing disease states are major areas of interest for the journal. This journal has been accepted for indexing on PubMed Central. The manuscript management system is completely online and includes a very quick and fair peer-review system, which is all easy to use. Visit http://www. dovepress.com/testimonials.php to read real quotes from published authors. 